\title{
Model Pembelajaran Kooperatif Tipe Pair Check untuk Meningkatkan Hasil Belajar Matematika Siswa Kelas V SD
}

\author{
Luh Redasi ${ }^{*}$ \\ ${ }^{1}$ SD Negeri 5 Sukasada, Singaraja, Indonesia
}

\section{ART I C LE IN F O}

Article history:

Received September 16, 2021

Revised September 18, 2021

Accepted October 20, 2021

Available online November 25, 2021

Kata Kunci:

Kooperatif Tipe Pair Check, Hasil Belajar

Keywords:

Cooperative Type Pair Check, Learning Outcomes

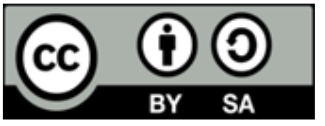

This is an open access article under the CC BY-SA license.

Copyright (@) 2021 by Author. Published by Universitas Pendidikan Ganesha.

\begin{abstract}
A B S T R A K
Rendahnya minat dan gairah belajar siswa terkait dengan mata pelajaran Matematika. Hal ini terjadi karena dalam mata pelajaran Matematika siswa harus berkutat dengan angka-angka dan rumusrumus yang terkadang terlihat kaku, tidak menarik, dan membosankan. Penelitian ini bertujuan meningkatkan hasil belajar Matematika melalui penerapan model pembelajaran kooperatif tipe Pair Check pada siswa kelas V SD. Penelitian ini adalah penelitian tindakan kelas yang melibatkan siswa kelas $V$ yang berjumlah 13 orang siswa. Sampel yang digunakan yaitu berjumlah siswa sebanyak 13 orang, terdiri dari 8 orang perempuan dan 5 orang lakilaki. Dalam penelitian ini, data hasil belajar siswa dikumpulkan dengan tes hasil belajar. Metode analisis data yang digunakan adalah analisis deskriptif. Hasil penelitian ini menunjukkan bahwa hasil belajar mata pelajaran Matematika melalui penerapan model pembelajaran kooperatif tipe Pair Check pada siswa kelas V dinyatakan meningkat. Hal ini dibuktikan dengan adanya perbedaan hasil belajar antara siklus I (jumlah 795, rata-rata 61, daya serap $61 \%$, ketuntasan belajar $46 \%$ ) dan siklus II (jumlah 910, rata-rata 70 , daya serap $70 \%$, ketuntasan belajar $92 \%$ ). Terjadi peningkatan hasil belajar antara siklus I dan siklus II menunjukkan adanya kenaikan rata-rata daya serap $9 \%$ dan pada ketuntasan belajar mengalami kenaikan sebesar $46 \%$. Ini berarti bahwa penerapan model pembelajaran kooperatif tipe Pair Check pada siswa kelas V SD dapat meningkatkan hasil belajar Matematika. Implikasi penelitian ini diharapkan dapat membantu guru dalam meningkatakan kemampuan kognitif siswa dengan menggunakan model kooperatif tipe pair check.
\end{abstract}

\section{A BS TRACT}

The students' low interest and enthusiasm for learning related to mathematics are because, in mathematics, students have to struggle with numbers and formulas that sometimes look stiff, unattractive, and boring. This study aims to improve mathematics learning outcomes by applying the Pair Check type cooperative learning model in fifth-grade elementary school students. This research is a classroom action research involving 13 students of class $V$. The sample used is 13 students, consisting of 8 women and five men. This study collected data on student learning outcomes using a learning outcome test. The data analysis method used is descriptive analysis. The results of this study indicate that the learning outcomes of Mathematics subjects through the application of the Pair Check type of cooperative learning model in fifth-grade students are increasing. It is proven that there are a difference in learning outcomes between cycle I (amount 795, average 61, absorption 61\%, complete learning 46\%) and cycles II (910 total, average 70, absorption 70\%, learning completeness 92\%). There was an increase in learning outcomes between cycle I and cycle II, showing an average increase in absorption of $9 \%$ and an increase of $46 \%$ in learning completeness. So, applying the Pair Check type of cooperative learning model in fifth-grade elementary school students can improve mathematics learning outcomes. The implications of this research are expected to help teachers improve students' cognitive abilities by using a pair check type cooperative model. 


\section{PENDAHULUAN}

Tujuan pembelajaran Matematika di sekolah, khusus di sekolah dasar (SD) agar peserta didik memiliki kemampuan seperti memahami konsep Matematika, menjelaskan keterkaitan antarkonsep dan mengaplikasikan konsep atau algoritma, secara luwes, akurat, efisien, dan tepat, dalam pemecahan (Anjarsari et al., 2020; Fiana et al., 2019; Rosa \& Clark, 2011). Mata pelajaran Matematika perlu diberikan kepada semua siswa melalui proses pembelajaran yang berkualitas dengan menerapkan model pembelajaran yang inovatif, sehingga materi yang diberikan dapat dikuasai oleh siswa serta proses pembelajarannya menjadi menarik, kontekstual, bervariasi, serta melibatkan peran aktif dari siswa (Bambang Sri Anggoro, 2016; Winoto \& Prasetyo, 2020). Dalam membelajarkan matematika kepada siswa, guru hendaknya lebih memilih berbagai variasi pendekatan, strategi, metode yang sesuai dengan situasi, sehingga tujuan pembelajaran yang direncanakan akan tercapai (Dini et al., 2018; Masykur et al., 2017; Rahayu \& Hidayati, 2018). Perlu diketahui bahwa baik atau tidaknya suatu pemilihan model pembelajaran akan bergantung pada tujuan pembelajarannya, kesesuaian dengan materi pembelajaran, tingkat perkembangan peserta didik (siswa), kemampuan guru dalam mengelola pembelajaran serta mengoptimalkan sumber-sumber belajar yang ada (Kurnia \& Damayani, 2019; Rufaidah, 2019). Untuk itu, salah satu tugas guru adalah bagaimana menyelenggarakan pembelajaran efektif.

Namun kenyataannya, proses pembelajaran Matematika di kelas V SD Negeri 5 Sukasada semester I tahun pelajaran 2019/2020 berjalan tidak sesuai dengan keinginan guru. Dalam mata pelajaran Matematika, siswa sudah langsung lesu darah jika kelas ada pelajaran Matematika. Siswa terlihat tidak bersemangat, gelisah, dan tidak menunjukkan sikap yang tertarik dengan mata pelajaran Matematika. Hal ini dapat dimaklumi sebab dalam mata pelajaran matematika, siswa harus berkutat dengan angka-angka dan rumus-rumus yang terkadang terlihat kaku, tidak menarik, dan membosankan. Rendahnya minat dan gairah belajar siswa terkait dengan mata pelajaran Matematika terlihat jelas dari hasil belajar tes awal yang diberikan oleh guru pada tanggal 5 Agustus 2019. Dari hasil belajar tersebut, diketahui bahwa rata-rata hasil belajar siswa sebesar 50, daya serap siswa sebesar 50\%, dan ketuntasan belajar siswa sebesar 31\%. Sedangkan dalam mata pelajaran Matematika, siswa dikatakan tuntas jika hasil belajarnya sebesar 65, daya serap sebesar $65 \%$ dengan ketuntasan belajar sebesar $85 \%$. Jika permasalahan tersebut dibiarkan maka akan memberikan dampak buruk terhadap pendidikan.

Solusi yang perlu dilakukan yaitu guru menerapkan model pembelajaran kooperatif tipe pair check untuk mengatasi permasalahan hasil belajar Matematika. Adapun pertimbangannya, model pembelajaran ini memiliki keunggulan karena mampu melatih kemandirian dan kemampuan siswa dalam menyelesaikan persoalan yang diberikan, sehingga dapat melatih rasa sosial siswa, kerja sama dan kemampuan memberi penilaian (Ahmad, 2016; Widiani, 2021). Pair check (pasangan mengecek) merupakan model pembelajaran berkelompok antar dua orang atau berpasangan (Ahmad, 2016; Ermavianti \& Sulistyorini, 2016; Melani et al., 2019). Model pembelajaran pair check adalah suatu tipe pembelajaran kooperatif yang berpasangan yang memiliki tujuan untuk mendalami atau melatih materi yang dipelajari (Ermavianti \& Sulistyorini, 2016; Farokah \& Winarso, 2021; Melani et al., 2019). Model ini menerapkan pembelajaran berkelompok yang menuntut kemandirian dan kemampuan siswa dalam menyelesaikan persoalan yang diberikan, sehingga dapat melatih rasa sosial siswa, kerja sama, dan kemampuan memberi penilaian (Farokah \& Winarso, 2021; Kamil et al., 2021; Surayya et al., 2014). Secara umum, sintaks dari pair check adalah (1) bekerja pasangan; (2) pembagian peran partner; (3) pelatihan memberi soal, partner menjawab, pengecekan jawaban; (4) bertukar peran; (5) penyimpulan; (6) evaluasi; dan (7) refleksi (Ermavianti \& Sulistyorini, 2016; Melani et al., 2019).

Beberapa temuan menyatakan bahwa model pembelajaran kooperatif tipe pair check mampu meningkatkan kerja sama antarsiswa, pengajaran teman sebaya (peer tutoring), meningkatkan pemahaman siswa mengenai konsep, dan melatih siswa berkomunikasi dengan baik (Rahayuni et al., 2018; Sartika, 2019). Model pembelajaran kooperatif tipe pair check dapat meningkatkan kemampuan berpikir kognitif siswa (Ermavianti \& Sulistyorini, 2016; Triwulandari et al., 2017; Vhalery \& Anggresta, 2021). Melalui penerapan model pembelajaran kooperatif tipe pair check, guru memiliki keyakinan bahwa model pembelajaran ini lebih baik daripada metode konvensional dalam mengatasi permasalahan hasil belajar yang dialami oleh siswa. Untuk itu, guru memutuskan untuk menerapkan model pembelajaran ini di kelas sebagai salah satu sarana untuk mencapai tujuan pembelajaran Matematika (Ahmad, 2016; Widiani, 2021). Berdasarkan kenyataan yang ada, maka perlu untuk meningkatkan hasil belajar siswa dalam mata pelajaran Matematika dengan menerapkan model ini dalam sebuah penelitian sederhana. Tujuan penelitian tindakan kelas ini adalah untuk meningkatkan hasil belajar Matematika melalu model pembelajaran kooperatif tipe pair check. Manfaat penelitian ini diharapkan dapat memberi alternatif pembelajaran baru untuk meningkatkan kemampuan berpikir kritis siswa. 


\section{METODE}

Penelitian ini adalah penelitian tindakan kelas yang dilaksanakan di kelas V SD Negeri 5 Sukasada dengan jumlah siswa sebanyak 13 orang, terdiri dari 8 orang perempuan dan 5 orang laki-laki. Penelitian ini dilaksanakan pada semester I tahun pelajaran 2019/2020 selama 4 bulan dari bulan Juli sampai dengan Oktober 2019. Penelitian ini dilakukan dengan menggunakan desain penelitian tindakan kelas (PTK) yang terdiri dari dua siklus. Penelitian tindakan kelas ini dilaksanakan sesuai dengan rancangan penelitian seperti pada gambar 1. Penelitian ini dimulai dari siklus I dimulai dengan perencanaan seperti: (1) menentukan materi yang akan menjadi pokok bahasan pada pertemuan selanjutnya, (2) menyusun rencana pelaksanaan pembelajaran (RPP) yang sesuai dengan apabila model pembelajaran kooperatif tipe pair check, (3) menyiapkan media pembelajaran berupa lembar kegiatan yang akan dikerjakan oleh tiaptiap kelompok, (4) menyiapkan lembar observasi untuk mencatat segala aktivitas belajar siswa, (5) menyiapkan alat perekam kegiatan belajar siswa berupa kamera digital, (6) menyusun instrument penilaian dan kunci jawaban, tes yang terdiri dari tes tulis yang berupa soal-soal pilihan ganda sebanyak 20 soal dengan empat option untuk mengetahui hasil belajar siswa tiap-tiap siklus.

Pada tahap pelaksanaan, dilaksanakan semua perencanaan pembelajaran yang telah disusun. Secara garis besar, aktivitas pelaksanaan pembelajaran yang dilakasanakan adalah sebgaia berikut.: (1) guru menjelaskan konsep;(2) Siswa dibagi ke dalam beberapa kelompok. Setiap kelompok terdiri dari empat orang. Dalam satu kelompok ada dua pasang. Setiap pasangan dalam satu kelompok dibebani satu peran yang berbeda, yaitu pelatih dan partner; (3) Guru membagikan soal kepada partner; (4) Partner menjawab soal, sedangkan pelatih akan mengecek jawabannya. Partner yang menjawab satu soal dengan benar berhak mendapatkan satu kupon dari pelatih; (5) Pelatih dan partner saling bertukar peran. Pelatih menjadi partner, sedangkan partner menjadi pelatih; (6) Guru membagikan soal kepada partner; (7) Partner menjawab soal, sedangkan pelatih akan mengecek jawabannya. Partner yang menjawab satu soal dengan benar berhak mendapatkan satu point dari pelatih; (8) Setiap pasangan kembali ke tim awal kemudian saling mencocokkan jawaban; (9) Guru membimbing dan memberikan arahan atas jawaban dari berbagai soal; (10) Setiap kelompok mengecek jawabannya; (11) Kelompok yang paling banyak mendapat point diberi hadiah atau reward oleh guru. Observasi merupakan pengamatan langsung terhadap objek yang diteliti. Data yang dikumpulkan dalam observasi adalah data tentang pembelajaran baik kelemahannya yang perlu diperbaiki maupun kelebihan pembelajaran yang perlu dipertahankan dalam siklus berikutnya.

Pada akhir kegiatan pembelajaran dilaksanakan evaluasi untuk mengetahui sejauh mana pemahaman siswa dalam kegiatan pembelajaran tersebut yang tercermin melalui hasil belajarnya. Evaluasi dilakukan dengan cara memberi 20 butir soal objektif (pilihan ganda) kepada siswa. Setiap jawaban benar diberikan skor 1 , sedangkan setiap jawaban salah diberikan skor 0. Skor maksimal idealnya adalah 100. Refleksi adalah sarana untuk melakukan pengkajian kembali terhadap tindakan yang telah dilakukan. Kegiatan refleksi ini berusaha mencari alur pemikiran yang logis, problem, dan hambatan yang muncul dalam pelaksanaan tindakan. Selain itu, kegiatan refleksi berguna untuk melakukan peninjauan, membuat gambaran kerja yang hidup dalam situasi proses penelitian, hambatan yang muncul dalam tindakan dan kemungkinan lain muncul selama proses penelitian. Adapun teknik pengumpulan data yang digunakan pada penelitian ini adalah metode tes. Tes adalah cara memperoleh data yang berbentuk suatu tugas yang harus dikejar oleh seseorang atau sekelompok orang yang dites (testee), dan dari tes dapat menghasilkan suatu skor, dan selanjutnya skor tersebut dibandingkan dengan suatu kriteria atau standar tertentu. Data yang menyangkut hasil belajar siswa dianalisis menggunakan analisis deskriptif yaitu dengan mencari rata-rata nilai siswa, daya serap ,dan ketuntasan belajar siswa.

\section{HASIL DAN PEMBAHASAN}

\section{Hasil}

Berdasarkan hasil penelitian dengan penerapan model pembelajaran kooperatif tipe pair check dalam pembelajaran matematika pada siswa kelas V SD Negeri 5 Sukasada semester I tahun pelajaran 2019/2020, disajikan pada Tabel 1. Hasil penelitian menunjukkan bahwa nilai rata-rata kelas mengalami peningkatan dari 50 pada hasil belajar prasiklus menjadi 61 pada siklus I, kemudian meningkat menjadi 70 pada siklus II. Sedangkan nilai daya serap siswa juga mengalami peningkatan dari 50\% pada prasiklus meningkat menjadi $61 \%$ pada siklus I, kemudian meningkat menjadi $70 \%$ pada siklus II. Ketuntasan belajar juga mengalami peningkatan dari $31 \%$ pada hasil belajar prasiklus, naik menjadi $46 \%$ pada siklus I, kemudian meningkat menjadi $92 \%$ pada siklus II. Pada prasiklus, hasil belajar siswa dapat digambarkan bahwa rata-rata hasil belajar sebesar 50, daya serap 50\% dengan ketuntasan belajar sebesar $31 \%$. Rendahnya hasil belajar ini disebabkan oleh metode ceramah. Penerapan metode tersebut menimbulkan efek kurang baik bagi siswa. Dalam pelajaran Matematika. siswa terlihat langsung lesu darah jika kelas. 
Siswa terlihat tidak bersemangat, gelisah, dan tidak menunjukkan sikap yang tertarik dengan mata pelajaran Matematika.

Pada siklus I, rata-rata hasil belajar 61, daya serap sebesar 61\% dengan ketuntasan belajar sebesar 46\%. Hasil belajar tersebut masih belum mencapai indikator keberhasilan yang ditetapkan dalam penelitian ini. Masih rendahnya hasil belajar tersebut disebabkan oleh: (1) siswa kurang aktif dalam sesi tanya jawab di awal pembelajaran, (2) Saat kerja berkelompok hanya beberapa siswa yang menjawab LKS yang diberikan, (3) pada saat mengerjakan LKS bersama kelompoknya, masih banyak kelompok yang kurang disiplin waktu. Hal ini terlihat dari pengerjaan LKS yang melebihi batas waktu yang telah ditetapkan, sehingga kekurangan waktu saat presentasi, (4) siswa kurang percaya diri dalam mencocokan jawabannya dengan partnernya sehingga jawaban yang digunakan adalah jawaban dari temannya, (5) siswa juga belum mampu mengecek jawaban temannya sehingga jawaban yang salah masih dibiarkan oleh siswa yang menjadi pelatih, (6) masih ada siswa yang kurang aktif dalam kegiatan kelompok, (7) siswa masih terbiasa mengandalkan teman yang lebih mampu untuk mengerjakan LKS, dan (8) kegiatan diskusi didominasi oleh siswa yang aktif.

Pada siklus II, rata-rata hasil belajar siswa sebesar 70 , daya serap sebesar $70 \%$ dengan ketuntasan belajar sebesar 92\%. Hasil belajar ini telah melampaui indikator keberhasilan yang ditetapkan dalam penelitian ini. Beberapa hal yang mengakibatkankan hasil belajar siswa meningkat pada siklus II adalah sebagai berikut. (1) Siswa aktif dalam sesi tanya jawab di awal pembelajaran; (2) Saat kerja berkelompok dan yang menjawab LKS yang diberikan secara bersama-sama; (3) Pada saat mengerjakan LKS bersama kelompoknya, sudah tepat waktu. Hal ini terlihat dari siswa yang siap berperan sebagai partner dan pelatih; (4) Siswa percaya diri dalam mencocokan jawabannya dengan partnernya sehingga jawaban yang digunakan adalah jawaban dari temannya; (5) Siswa mampu mengecek jawaban temannya sehingga jawaban yang salah bisa dikoreksi oleh pelatihnya: (6) Reward yang diberikan mampu meningkatkan motivasi siswa. Meningkatnya hasil belajar siswa pada siklus II disebabkan oleh penerapan model pembelajaran kooperatif tipe pair check yang optimal, sehingga proses pembelajaran menjadi efektif dan efesien.

Tabel 1. Perkembangan Hasil Belajar

\begin{tabular}{ccccc}
\hline Uraian & Pra Siklus & Siklus I & Siklus II & Peningkatan \\
\hline Jumlah & 650 & 795 & 910 & 115 \\
Rata-rata Kelas & 50 & 61 & 70 & 9 \\
Daya Serap & $50 \%$ & $61 \%$ & $70 \%$ & $9 \%$ \\
Ketuntasan Belajar & $31 \%$ & $46 \%$ & $92 \%$ & $46 \%$ \\
\hline
\end{tabular}

\section{Pembahasan}

Berdasarkan hasil penelitian, penerapan model pembelajaran kooperatif tipe pair check yang optimal, sehingga proses pembelajaran menjadi efektif dan efesien. Model pembelajaran pair check menuntut siswa untuk saling berbagi dalam kemampuan kognitifnya, sehingga terjadi saling tukar pendapat dan melatih agar siswa aktif dalam proses pembelajaran. Pada proses saling berbagi dalam kemampuan kognitifnya membuat siswa lain tidak sungkan bertanya dengan temannya yang lebih mengerti. Setiap siswa juga dituntut untuk memiliki tanggung jawab terhadap tugasnya masing-masing. Adapun keunggulan model pembelajaran kooperatif tipe pair check adalah meningkatkan kerja sama antarsiswa, pengajaran teman sebaya (peer tutoring), meningkatkan pemahaman siswa mengenai konsep, dn melatih siswa berkomunikasi dengan baik (Asrini, 2020; Rahayuni et al., 2018). Model pembelajaran pair check adalah suatu tipe pembelajaran kooperatif yang berpasangan yang memiliki tujuan untuk mendalami atau melatih materi yang dipelajari (Ermavianti \& Sulistyorini, 2016; Irdianto et al., 2019). Model ini menerapkan pembelajaran berkelompok yang menuntut kemandirian dan kemampuan siswa dalam menyelesaikan persoalan yang diberikan, sehingga dapat melatih rasa sosial siswa, kerja sama, dan kemampuan memberi penilaian.

Model kooperatif tipe pair check efek digunakan untuk melatih siswa memberikan dan menerima motivasi dari pasangannya secara tepat dan efektif. Motivasi antarteman sangat diperlukan dalam proses pembelajaran. Motivasi belajar siswa selama proses pembelajaran juga merupakan indikator keberhasilan dalam proses pembelajaran (Harni, 2021; Puspitorini et al., 2014; Rizqi \& Sumantri, 2019). Selain itu, dengan model pembelajaran kooperatif tipe pair check dapat meningkatkan keaktifan siswa dalam pembelajaran di kelas karena dalam kelompok tersebut sudah memiliki peran masing-masing yakni sebagai partner dan coach, sehingga siswa sangat antusias dan termotivasi untuk menjalankan peran meraka masing-masing. Dengan peran yang dimiliki memberikan kesempatan pada siswa untuk membimbing orang lain (pasangannya) (Arifin \& Aprisal, 2020). Motivasi dan aktivitas yang dapat dikembangkan model pembelajaran kooperatif tipe pair check ini selain akan memengaruhi aspek kognitif 
peserta didik (kemampuan berpikir kreatif) yang bepengaruh pada meningkatnya kemampuan pemecahan masalah matematika peserta didik, juga diharapkan melalui model pembelajaran kooperatif tipe pair check tersebut dapat mengembangkan aspek nonkognitif dari kreativitas yakni kepribadian kreatif, kritis, social skill, dan sikap aktif peserta didik.

Temuan ini diperkuat dengan penelitian sebelumnya yang menyatakan adanya peningkatan hasil belajar Matematika melalui penerapan model pembelajaran kooperatif tipe pair check (Melani et al., 2019; Widiani, 2021). Model pembelajaran kooperatif tipe pair check mampu meningkatkan kerja sama antar siswa, pengajaran teman sebaya (peer tutoring), meningkatkan pemahaman siswa mengenai konsep, dan melatih siswa berkomunikasi dengan baik (Rahayuni et al., 2018; Sartika, 2019). Model pembelajaran kooperatif tipe pair check dapat meningkatkan kemampuan berpikir kognitif siswa (Ermavianti \& Sulistyorini, 2016; Triwulandari et al., 2017; Vhalery \& Anggresta, 2021). Berdasarkan pembahasan, model kooperatif tipe pair check dapat digunakan pada proses pembelajaran matematika. Selain itu, model ini bisa diterapkan pada pembelajaran lainnya. Namun, model kooperatif tipe pair check ini memiliki kekurangan dalam penerapannya, yaitu membutuhkan waktu yang lama. Implikasi penelitian ini diharapkan dapat membantu guru dalam meningkatakan kemampuan kognitif siswa dengan menggunakan model kooperatif tipe pair check.

\section{SIMPULAN}

Penerapan model pembelajaran kooperatif tipe pair check dapat meningkatkan hasil belajar Matematika pada siswa. Guru hendaknya menerapkan model pembelajaran ini sebab model pembelajaran ini mampu meningkatkan pemahaman siswa terhadap materi pelajaran. Selain itu, model pembelajaran ini dapat dijadikan sebagai salah satu alternatif pembelajaran di sekolah dengan terlebih dahulu memberikan pemahaman kepada guru-guru lainnya untuk mencoba model pembelajaran ini.

\section{DAFTAR RUJUKAN}

Ahmad, F. (2016). Penerapan Model Pembelajaran Kooperatif Tipe Pair Checks dalam Meningkatkan Motivasi dan Hasil Belajar IPA Tepadu Siswa Kelas VIIIA SMP Negeri 1 Tabulahan Kab. Mamasa. Sainsmat, 5(2), 137-142. http://ojs.unm.ac.id/index.php/sainsmat/article/view/3241/1859.

Anjarsari, E., Farisdianto, D. D., \& Asadullah, A. W. (2020). Pengembangan Media Audiovisual Powtoon pada Pembelajaran Matematika untuk Siswa Sekolah Dasar. Jurnal Matematika Dan Pendidikan Matematika, 5(2), 40-50. https://doi.org/10.26594/jmpm.v5i2.2084.

Arifin, S., \& Aprisal, A. (2020). Penerapan Model Pembelajaran Kooperatif Tipe Pair Checks terhadap Kemampuan Pemecahan Masalah Matematika. Jurnal Pendidikan Matematika, 11(1), 89-98. https://doi.org/10.36709/jpm.v11i1.9974.

Asrini, N. W. (2020). Meningkatkan Prestasi Belajar IPS Melalui Penggunaan Model Pembelajaran Pair Check. Journal of Education Action Research, 4(3), 338-344. https://doi.org/10.23887/jear.v4i3.27402.

bambang sri anggoro. (2016). Meningkatkan Kemampuan Generalisasi Matematis melalui Discovery Learning dan Model Pembelajaran Peer Led Guided Inquiry. Al-Jabar: Jurnal Pendidikan Matematika, 7(1), 15. https://doi.org/10.24042/ajpm.v7i1.23.

Dini, M., Wijaya, T. T., \& Sugandi, A. I. (2018). Pengaruh Self Confidence terhadap Kemampuan Pemahaman Matematik Siswa SMP. JURNAL SILOGISME : Kajian Ilmu Matematika Dan Pembelajarannya, 3(1), 1. https://doi.org/10.24269/js.v3i1.936.

Ermavianti, D., \& Sulistyorini, W. (2016). Model Pembelajaran Kooperatif Tipe Pair Check untuk Membangun Keterampilan Bertanya Produktif Siswa. Jurnal Pendidikan Teknologi Dan Kejuruan, 23(1), 1-15. https: //doi.org/10.21831/jptk.v23i1.9350.

Farokah, E., \& Winarso, W. (2021). Mathematical Communication and Social Skills of The Students through Pair Check Type Cooperative Learning Models. Sukma: Jurnal Pendidikan, 5(2), 133-150. https://doi.org/10.32533/\%25x.

Fiana, R. O., Relmasira, S. C., \& Hardini, A. T. A. (2019). Perbedaan Penerapan Model Project Based Learning dan Problem Based Learning terhadap Hasil Belajar Matematika Kelas 4 SD. Jurnal Basicedu, 3(1), 157 - 162. https://doi.org/10.31004/basicedu.v3i1.95.

Harni. (2021). Penerapan Model Pembelajaran Inkuiri untuk Meningkatkan Motivasi dan Hasil Belajar Siswa pada Materi Cahaya dan Sifat-Sifatnya di SD Negeri 2 Uebone. Jurnal Paedagogy, 8(2), 181189. https://doi.org/10.33394/jp.v8i2.3481.

Irdianto, W., Poerwanto, E. E., \& Ihwanudin, M. (2019). The Improvement Of Basic Measurement Skills through Pair Check Type Cooperative Learning Models. Jurnal Ilmu Pendidikan, 24(2), 86-89. 
https://doi.org/10.17977/um048v24i2p86-89.

Kamil, V. R., Arief, D., Miaz, Y., \& Rifma, R. (2021). Pengaruh Penggunaan Model Pembelajaran Kooperatif Tipe Think Pair Share terhadap Motivasi dan Hasil Belajar Belajar Siswa Kelas VI. Jurnal Basicedu, 5(6), 6025-6033. https://doi.org/10.31004/basicedu.v5i6.1744.

Kurnia, V. T., \& Damayani, A. T. (2019). Keefektifan Model Pembelajaran Number Head Together ( NHT ) Berbantu Media Puzzle terhadap Hasil Belajar Matematika. Jurnal Ilmiah Sekolah Dasar, 3(2), 192-201. https://doi.org/10.23887/jisd.v3i2.17772.

Masykur, R., Nofrizal, N., \& Syazali, M. (2017). Pengembangan Media Pembelajaran Matematika dengan Macromedia Flash. Al-Jabar: Jurnal Pendidikan Matematika, 8(2), 177. https://doi.org/10.24042/ajpm.v8i2.2014.

Melani, A. E. T., Candiasa, I. M., \& Hartawan, I. G. N. Y. (2019). Pengaruh Penerapan Model Pembelajaran Pair Check terhadap Kemampuan Numerik Siswa Kelas VII SMP Negeri 3 Gianyar. Jurnal Pendidikan Matematika Undiksha, 10(1), 1-10. https://doi.org/10.23887/jjpm.v10i1.19900.

Puspitorini, R., Prodjosantoso, A. K., Subali, B., \& Jumadi, J. (2014). Penggunaan Media Komik dalam Pembelajaran IPS untuk Meningkatkan Motivasi dan Hasil Belajar Kognitif dan Afektif. Jurnal Cakrawala Pendidikan, 3(3), 413-420. https://doi.org/10.21831/cp.v3i3.2385.

Rahayu, S., \& Hidayati, W. N. (2018). Meningkatkan Hasil Belajar Matematikam melalui Penggunaan Media Bangun Ruang dan Bangun Datar pada Siswa Kelas V SDN Jomin Barat I Kecamatan Kotabaru Kabupaten Karawang. Jurnal Pendidikan Sekolah Dasar, 4(2), 204. https://doi.org/10.30870/jpsd.v4i2.3854.

Rahayuni, N. P. A., Asri, I. A. S., \& Suniasih, N. W. (2018). Pengaruh Model Pembelajaran Pair Check Berbasis Penilaian Kinerja terhadap Kompetensi Pengetahuan PKn Siswa Kelas IV. Mimbar Ilmu, 23(1), 65-72. https://doi.org/10.23887/mi.v23i1.16408.

Rizqi, A. T., \& Sumantri, M. (2019). Hubungan Antara Motivasi Belajar dan Pola Asuh Orang Tua terhadap Hasil Belajar IPA. Jurnal Imiah Pendidikan Dan Pembelajaran, 3(2), 145-154. https://doi.org/10.23887/jipp.v3i2.18071.

Rosa, M., \& Clark, D. (2011). Ethnomathematics: The Cultural Aspects of Mathematics. Revista Latinoamericana de Etnomatemática: Perspectivas Socioculturales de La Educación Matemática, $4(2), 32-54$.

Rufaidah, R. (2019). Peningkatan Kemampuan Komunikasi Matematis melalui Model Pembelajaran Kooperatif Tipe Think Talk Write (Ttw) dengan Media LKPD pada Materi Relasi dan Fungsi Siswa Kelas VIII-B MTs Al-Ma'Arif Bocek Karangploso Tahun Pelajaran 2017/2018. JPM: Jurnal Pendidikan Matematika, 4(2), 95. https://doi.org/10.33474/jpm.v4i2.2621.

Sartika, N. S. (2019). Pengembangan Model Pair Check untuk Menghindari Mind in Chaos Siswa Kelas X terhadap Pembelajaran Matematika. FIBONACCI: Jurnal Pendidikan Matematika Dan Matematika, 5(2), 97-104. https://doi.org/10.24853/fbc.5.2.97-104.

Surayya, L., Subagia, I. W., \& Tika, I. N. (2014). Pengaruh Model Pembelajaran Think Pair Share terhadap Hasil Belajar Fisika Siswa Ditinjau dari Keterampilan Berpikir Kritis Siswa. Jurnal Pendidikan Dan Pembelajaran IPA Indonesia, 4, 1. https://doi.org/10.24127/jpf.v7i1.1396.

Triwulandari, D., Wati, M., \& Miriam, S. (2017). Perbedaan Hasil Belajar Siswa antara Menggunakan Model Pembelajaran Kooperatif Tipe Think Pair Share dengan Tipe Pair Checks. Berkala Ilmiah Pendidikan Fisika, 5(1), 99-108. https://doi.org/10.20527/bipf.v5i1.2816.

Vhalery, R., \& Anggresta, V. (2021). Perbedaan Kemampuan Analisis melalui Model Pembelajaran Kooperatif Tipe Pair Check dengan Make a Match. Jurnal Inovasi Pendidikan Ekonomi (JIPE), 11(1), 01-13. https://doi.org/10.24036/011109490.

Widiani, N. L. (2021). Penerapan Model Pembelajaran Kooperatif Tipe Pair Check untuk Meningkatkan Hasil Belajar Matematika. Journal of Education Action Research, 5(2), 278-284. https://doi.org/10.23887/jear.v5i2.33312.

Winoto, Y. C., \& Prasetyo, T. (2020). Efektivitas Model Problem Based Learning dan Discovery Learning terhadap Kemampuan Berpikir Kritis Siswa Sekolah Dasar. Jurnal Basicedu, 4(2), 228-238. https://doi.org/10.31004/basicedu.v4i2.348. 